\title{
Drought-induced reduction in methane fluxes and its hydrothermal sensitivity in alpine peatland
}

\author{
Haidong Wu ${ }^{\text {Equal first author, 1, 2, } 3}$, Liang Yan Equal first author, 1, 2,3 , Yong Li ${ }^{1,2,3}$, Kerou Zhang ${ }^{1,2,3}$, Yanbin Hao ${ }^{4}$, Jinzhi Wang ${ }^{1,2,3}$, \\ Xiaodong Zhang ${ }^{1,2,3}$, Zhongqing Yan ${ }^{1,2,3}$, Yuan Zhang ${ }^{4}$, Xiaoming Kang ${ }^{\text {Corresp. 1, 2, } 3}$ \\ 1 Institute of Wetland Research, Chinese Academy of Forestry, Beijing, China \\ 2 Beijing Key Laboratory of Wetland Services and Restoration, Beijing, China \\ 3 Sichuan Zoige Wetland Ecosystem Research Station, Tibetan Autonomous Prefecture of Aba, China \\ 4 University of Chinese Academy of Science, Beijing, China \\ Corresponding Author: Xiaoming Kang \\ Email address: xmkang@ucas.ac.cn
}

Accurate estimation of $\mathrm{CH}_{4}$ fluxes in alpine peatland of the Qinghai-Tibetan Plateau under extreme drought is vital for understanding the global carbon cycle and predicting future climate change. However, studies on the impacts of extreme drought on peatland $\mathrm{CH}_{4}$ fluxes are limited. To study the effects of extreme drought on $\mathrm{CH}_{4}$ fluxes of the Zoige alpine peatland ecosystem, the $\mathrm{CH}_{4}$ fluxes during both extreme drought treatment (D) and control treatment (CK) were monitored using a static enclosed chamber in a control platform of extreme drought. The results showed that extreme drought significantly decreased $\mathrm{CH}_{4}$ fluxes in the Zoige alpine peatland by $31.54 \%(P<0.05)$. Extreme drought significantly reduced the soil water content $(S W C)(P<0.05)$, but had no significant effect on soil temperature (Ts). Under extreme drought and control treatments, there was a significant negative correlation between $\mathrm{CH}_{4}$ fluxes and environmental factors (Ts and SWC), except Ts, at a depth of $5 \mathrm{~cm}(P<0.05)$. Extreme drought reduced the correlation between $\mathrm{CH}_{4}$ fluxes and environmental factors and significantly weakened the sensitivity of $\mathrm{CH}_{4}$ fluxes to SWC $(P<0.01)$. Moreover, it was found that the correlation between subsoil $(20 \mathrm{~cm})$ environmental factors and $\mathrm{CH}_{4}$ fluxes was higher than with the topsoil $(5,10 \mathrm{~cm})$ environmental factors under the control and extreme drought treatments. These results provide a better understanding of the extreme drought effects on $\mathrm{CH}_{4}$ fluxes of alpine peatland, and their hydrothermal impact factors, which provides a reliable reference for peatland protection and management. 


\section{Drought-induced reduction in methane fluxes and its 2 hydrothermal sensitivity in alpine peatland}

3

4 5 6

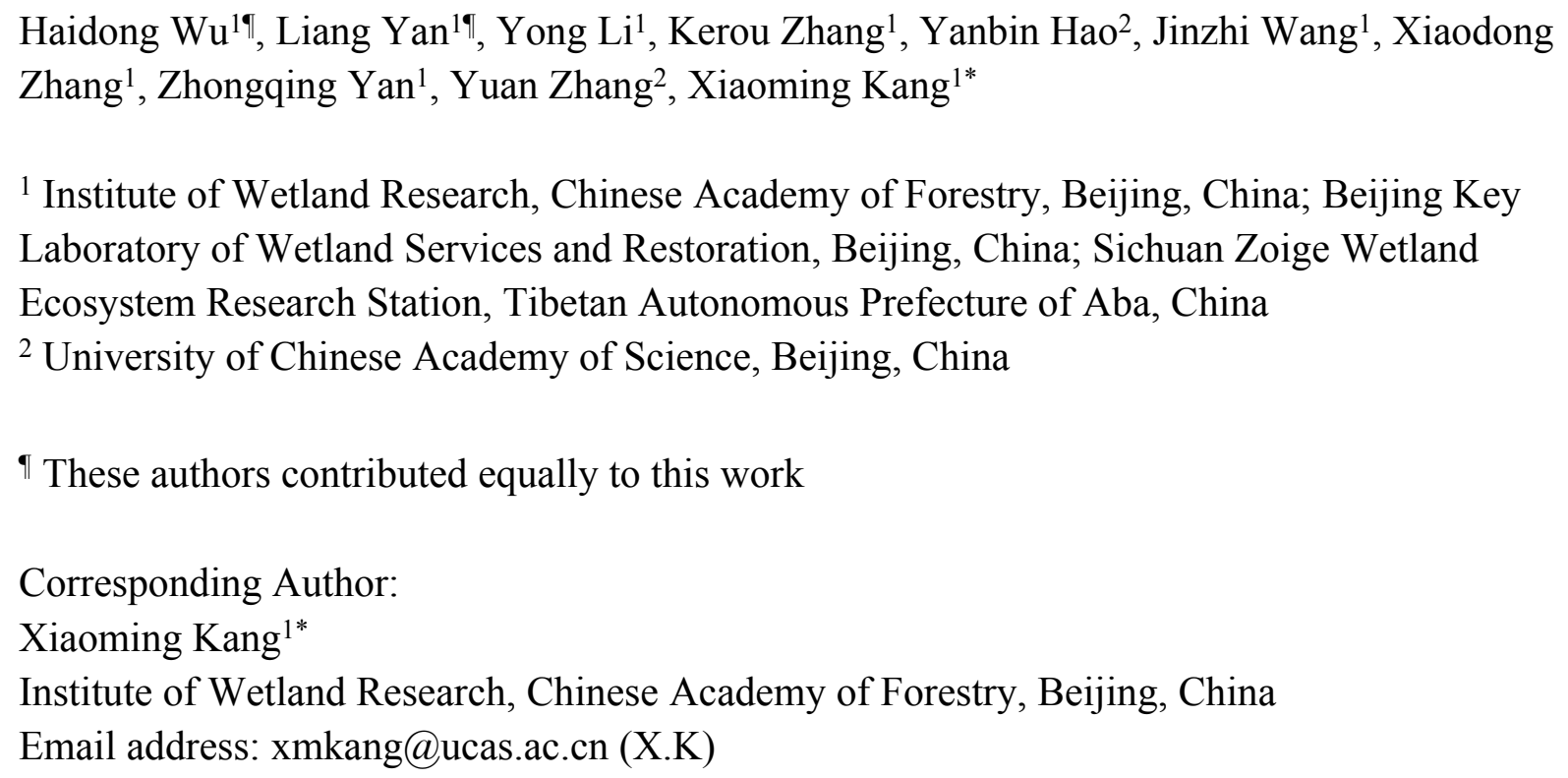

\section{Abstract}

Accurate estimation of $\mathrm{CH}_{4}$ fluxes in alpine peatland of the Qinghai-Tibetan Plateau under extreme drought is vital for understanding the global carbon cycle and predicting future climate change. However, studies on the impacts of extreme drought on peatland $\mathrm{CH}_{4}$ fluxes are limited. To study the effects of extreme drought on $\mathrm{CH}_{4}$ fluxes of the Zoige alpine peatland ecosystem, the $\mathrm{CH}_{4}$ fluxes during both extreme drought treatment (D) and control treatment (CK) were monitored using a static enclosed chamber in a control platform of extreme drought. The results showed that extreme drought significantly decreased $\mathrm{CH}_{4}$ fluxes in the Zoige alpine peatland by $31.54 \%(P<0.05)$. Extreme drought significantly reduced the soil water content (SWC) $(P<0.05)$, but had no significant effect on soil temperature (Ts). Under extreme drought and control treatments, there was a significant negative correlation between $\mathrm{CH}_{4}$ fluxes and environmental factors (Ts and SWC), except Ts, at a depth of $5 \mathrm{~cm}(P<0.05)$. Extreme drought reduced the correlation between $\mathrm{CH}_{4}$ fluxes and environmental factors and significantly weakened the sensitivity of $\mathrm{CH}_{4}$ fluxes to SWC $(P<0.01)$. Moreover, it was found that the correlation between subsoil $(20 \mathrm{~cm})$ environmental factors and $\mathrm{CH}_{4}$ fluxes was higher than with the topsoil $(5,10$ $\mathrm{cm}$ ) environmental factors under the control and extreme drought treatments. These results provide a better understanding of the extreme drought effects on $\mathrm{CH}_{4}$ fluxes of alpine peatland, and their hydrothermal impact factors, which provides a reliable reference for peatland protection and management.

Keywords: extreme drought; alpine peatland; $\mathrm{CH}_{4}$ fluxes; hydrothermal sensitivity 
40

41

42

43

44

45

46

47

48

49

50

51

52

53

54

55

56

57

58

59

60

61

62

63

64

65

66

67

68

69

70

71

72

73

74

75

76

77

78

79

\section{Introduction}

In recent years, due to the aggravation caused by human activities, the global atmospheric and water cycle pattern has been significantly changed, resulting in an increasing frequency and intensity of global extreme climate events [1-4]. Recent studies have indicated that the occurrence of extreme drought events can significantly change the water and heat conditions of the ecosystem, affecting the physiological state of plants and activities of soil microbes, triggering changes in the soil structure and function, and breaking the original carbon balance of the ecosystem, which in turn can aggravate the intensity and frequency of extreme drought events on a global scale [5-8]. However, research on extreme drought is still concentrated in arid and semi-arid grasslands at present, and research on peatland is relatively rare [6-7,9]. As an important global carbon pool, peatlands are carbon-rich ecosystems that cover just 3\% of the Earth's land surface, but they store one-third of the soil carbon [10-11]. As such, peatlands play an important role in the global carbon cycle and mitigation of climate change [12].

The alpine peatland ecosystem, on account of its special altitude, presentsa higher sensitivity to climate change [13]. Additionally, with low temperatures and anoxia all year round, peatlands have sequestered large amounts of carbon in the soil [14-15]. However, when disturbed by external conditions, the source and sink of $\mathrm{CH}_{4}$ in the alpine peatland ecosystem can be significantly altered [16]. As one of the main greenhouse gases, the warming potential of $\mathrm{CH}_{4}$ is 23 times than that of $\mathrm{CO}_{2}$, and changes in the $\mathrm{CH}_{4}$ content in the atmosphere can have a significant impact on the trend and intensity of global climate change [17-18]. However, the dynamics of $\mathrm{CH}_{4}$ in alpine peatland ecosystems and its response to extreme drought are poorly understood and lack quantified analyses. Therefore, accurate quantification of alpine peatland $\mathrm{CH}_{4}$ fluxes under extreme drought conditions at various spatial and temporal scales is crucial and necessary for fully understanding the climate change process.

The Zoige plateau, located in the northeast of the Qinghai-Tibet plateau, is the region with the highest organic carbon reserves in China and one of the largest plateau peatlands in the world, thus playing an important role in the global carbon cycle [19]. As such, this region could potentially have a significant impact on regional climate change [20]. However, due to the warming and drying trends that have occurred over the past 30 years, the surface water level of the Zoige peatland has decreased substantially, which directly alters the pattern of $\mathrm{CH}_{4}$ fluxes in this area [21-24]. Moreover, changes in precipitation and atmospheric temperatures, as well as the effects of decreased water levels, serve to increase the level of uncertainty regarding the magnitude of the $\mathrm{CH}_{4}$ fluxes occurring in many ecosystems [24-25]. Therefore, to improve our understanding of the $\mathrm{CH}_{4}$ dynamics occurring in the Zoige alpine peatland, the effects of temperature and precipitation variability under extreme drought conditions should be studied simultaneously.

In recent years, researchers have found that $\mathrm{CH}_{4}$ uptake is strongly controlled by soil moisture, as soil temperature only has a minor influence on $\mathrm{CH}_{4}$ fluxes measured at the Tasmania Ecological Research site [26]. Daily observations of $\mathrm{CH}_{4}$ fluxes in nine different types of 
80

81

82

83

84

85

86

87

88

89

90

91

92

93

94

95

96

97

98

99

100

101

102

103

104

105

106

107

108

109

110

111

112

113

114

115

116

117

118

swamps in northern Finland have shown that the average $\mathrm{CH}_{4}$ emission is significantly correlated with the average groundwater level [27]. Related research has also indicated that the yield of $\mathrm{CH}_{4}$ is lower under drought conditions in peatlands [28]. Moreover, frequent extreme drought events in recent years have been increasing, and these events have clearly had a profound impact on $\mathrm{CH}_{4}$ fluxes in the Zoige peatland [29-30]. However, data regarding the changes in $\mathrm{CH}_{4}$ fluxes in the Zoige peatland under extreme drought are limited.

Therefore, the accurate estimation of $\mathrm{CH}_{4}$ fluxes and the factors impacting their dynamics will help quantify the interactions and feedback occurring between extreme drought events and the alpine peatland ecosystem. In this study, we observed the $\mathrm{CH}_{4}$ fluxes and environmental factors at the Zoige peatland in a controlled experiment of extreme drought with the hope of estimating the drought effects on $\mathrm{CH}_{4}$ fluxes, and we identified the environmental variables affecting these fluxes under continuous drought stress. The results provide an important scientific basis to accurately evaluate the contribution of alpine peatland $\mathrm{CH}_{4}$ towards global climate change and will also help support peatland conservation.

\section{Materials \& Methods}

\subsection{Site description}

The experiment was conducted in Zoige county in the eastern Tibetan Plateau $\left(33.79^{\circ} \mathrm{N}, 102.95^{\circ}\right.$ E) at an altitude of $3430 \mathrm{~m}$ (Figure 1a). The mean annual temperature is $1.1^{\circ} \mathrm{C}$, and mean annual precipitation is $648.5 \mathrm{~mm}$, with $80 \%$ falling during the growing season from June to September. The mean monthly temperature ranges from $1{ }^{\circ} \mathrm{C}$ (January) to $11^{\circ} \mathrm{C}$ (July). The experiment was established in a frigid temperate zone steppe dominated by herbaceous marshes and composed mainly of Carex meyeriana, Carex muliensis, and Kobresia tibetica. The main soil type was marshy peat, with the soil $\mathrm{pH}$ is between 6.8-7.2 in localized areas [31]. The depth of peat in the vertical profile of this site is in general $1.2 \mathrm{~m}$. Field experiments were approved by the Institute of Wetland Research.

\subsection{Experiment design and data collection}

Based on the local rainfall data for the past 50 years, we defined daily rainfall $\geq 3 \mathrm{~mm}$ as ecologically effective precipitation [32]. During the flourishing period of the growth season, we selected 32 days as the duration of non-ecologically effective precipitation (drought days) and simulated extreme drought over this period of plant growth [33]. The area of the plot was $20 \mathrm{~m} \times$ $20 \mathrm{~m}$, and extreme drought treatment (D) and control treatments (CK) were set up, independently, with each treatment consisting of three $(2 \mathrm{~m} \times 2 \mathrm{~m})$ repetition plots (Figure $1 \mathrm{~b}$ ). We buried iron sheets in the soil about $1 \mathrm{~m}$ deep around each treatment to prevent the lateral flow of soil water. A stainless-steel base $(50 \mathrm{~cm} \times 50 \mathrm{~cm} \times 20 \mathrm{~cm})$ was placed at the sampling point and inserted into the ground at a depth of $10 \mathrm{~cm}$. Before each measurement, we filled the groove of stainless steel with water to ensure the airtightness of the measurement (Figure 1c). For the extreme drought treatment, we used a magnesium-aluminum alloy shelter (length $\times$ width 
119

120

121

122

123

124

125

126

127

128

129

130

131

132

133

134

135

136

137

138

139

140

141

142

143

144

145

146

147

148

149

150

151

152

153

154

155

156

157

158

$\times$ height; $2.5 \mathrm{~m} \times 2.5 \mathrm{~m} \times 1.8 \mathrm{~m}$ ) to simulate drought, and the light transmittance of the shelter was more than $90 \%$. The gas in the controlled plot was monitored under natural conditions.

A fast greenhouse gas analyzer (DLT-100, Los Gatos Research, USA) was used to monitor $\mathrm{CH}_{4}$ fluxes, at a data acquisition frequency of $1 \mathrm{~Hz}$. A TZS-5X thermometer was used to monitor the air temperature (Ta) and soil temperature (Ts), and a TDR 300 was used to measure the SWC. A box $(50 \mathrm{~cm} \times 50 \mathrm{~cm})$ was connected with the fast greenhouse gas analyzer. There were two small holes $2 \mathrm{~cm}$ in diameter at the top of the box, which were closed with rubber plugs. There was a small hole in each rubber plug for the insertion of two gas conduits (intake pipe and outlet pipe) with a length of $20 \mathrm{~m}$ and an inner diameter about $4 \mathrm{~mm}$. The box was connected to an intake pipe and an outlet pipe with a length of about $20 \mathrm{~m}$. To ensure the gas in the box could be quickly mixed and evenly distributed, two small fans $(10 \mathrm{~cm}$ in diameter) were set at the top of the box. Each sampling point was measured in a sealed transparent box or dark box for $2 \mathrm{~min}$, and the measured data from the dark box were used to ascertain the $\mathrm{CH}_{4}$ fluxes. The drought treatment started on July 15, 2017, and end on August 16, 2017. The measurements were taken at three periods of one day (first: 9:00- 10:00, second: 12:00-13:00, third: 14:00-15:00). For the measurement of aboveground biomass, $50 \mathrm{~cm} \times 50 \mathrm{~cm}$ quadrats were randomly chosen in each experimental plot, and all plants within the quadrats were cut to ground level. After the dust was removed, the plant material was oven dried to constant weight at $70^{\circ} \mathrm{C}$. Belowground biomass was collected by digging soil pits at the same locations where the aboveground biomass had been removed at the sampling depths of $0-20 \mathrm{~cm}$ and $20-40 \mathrm{~cm}$. Soils containing root biomass were placed in 40-mesh nylon bags and taken back to the laboratory, where the roots were carefully washed and then oven dried to a constant weight at $70{ }^{\circ} \mathrm{C}$. A soil drill was used to sample the soil via multi-point sampling and mixing. The soil organic matter (SOC) was determined using a potassium dichromate volumetric method [33], total carbon (TC) was determined by the elemental analyzer [34], and total nitrogen (TN) was determined via the Kjeldahl method [35].

\subsection{Data analysis}

The formula used for calculating the greenhouse gas fluxes [36] was:

$\mathrm{F}_{\mathrm{C}}=\frac{\partial \mathrm{C}^{\prime}}{\partial \mathrm{t}} \times \frac{\mathrm{M}}{\mathrm{V}_{0}} \times \frac{\mathrm{P}}{\mathrm{P}_{0}} \times \frac{\mathrm{T}_{0}}{\mathrm{~T}_{0}+\mathrm{t}} \times \frac{\mathrm{H}}{100} \times 3600$

Where $\mathrm{Fc}$ is the gas fluxes $(\mathrm{mg} \mathrm{C} /(\mathrm{m} 2 \cdot \mathrm{h})) ; \mathrm{M}$ is the molar mass of gas $(\mathrm{g} / \mathrm{mol}) ; \mathrm{V}_{0}$ is the standard molar volume of gas $(22.4 \mathrm{~L} / \mathrm{mol}) ; \mathrm{P} / \mathrm{P}_{0}$ is the measurement of pressure to standard air pressure; $\mathrm{T}_{0}$ is the absolute temperature $\left(273.15^{\circ} \mathrm{C}\right) ; \mathrm{t}$ is the average value of the measured temperature in the box $\left({ }^{\circ} \mathrm{C}\right)$; and $\mathrm{H}$ is the static height $(\mathrm{cm})$. Importantly, the measured data were analyzed by linear regression to calculate the linear slope of the gas concentration relative to the time of observation.

Repeated-measure ANOVA with Duncan's multiple-range tests were performed to examine the main and interaction effects of date, treatment and block on the differences in $\mathrm{CH}_{4}$ fluxes and environmental factors in 2017 (SPSS, Chicago, IL, USA). A one-way ANOVA analysis was performed to examine the properties (above and below ground biomass, TC, TN, SOC) at different depths in 2017 (SPSS, Chicago, IL, USA). To further evaluate the relationship of $\mathrm{CH}_{4}$ fluxes and environmental factors, a correlation matrix analysis between $\mathrm{CH}_{4}$ fluxes and 
159

160

161

162

163

164

165

166

167

168

169

170

171

172

173

174

175

176

177

178

179

180

181

182

183

184

185

186

187

188

189

190

191

192

193

194

195

196

197

198

environmental factors was conducted (Origin 2017, USA). The slopes of those linear relationships were analyzed and compared by SMA (Standardized Major Axis) regression analysis, using the SMATR (Standardized Major Axis Tests and Routines) package [37]. R v3.5.1 with the corrplot package was used for the correlation analysis [38].

\section{Results}

\subsection{Climate during the experiment period}

During the experiment period (32 d), 14 precipitation events occurred in Zoige, with 6 days including ecologically effective precipitation events $(\geq 3 \mathrm{~mm})$. The daily precipitation ranged from $0.1 \mathrm{~mm}$ to $20.6 \mathrm{~mm}$ (Figure 2) and the average precipitation was $1.9 \mathrm{~mm}$. The total precipitation was $58.9 \mathrm{~mm}$ in the control treatment and $0 \mathrm{~mm}$ in the extreme drought treatment during the experimental period. The precipitation mainly occurred in early August, and a transient rainfall occurred at the end of the treatment period. The highest and lowest daily temperatures were $15.3{ }^{\circ} \mathrm{C}$ and $8.4{ }^{\circ} \mathrm{C}$, respectively, and the average temperature was $12.9^{\circ} \mathrm{C}$ during the treatment period.

\subsection{Effects of extreme drought on $\mathrm{CH}_{4}$ fluxes}

From the end of June to the middle of July, there was a transition period between a weak $\mathrm{CH}_{4}$ sink and a weak $\mathrm{CH}_{4}$ source of the Zoige peatland (Figure 3a). The emission of $\mathrm{CH}_{4}$ from the Zoige peatland reached a maximum around August 16. During the pre-drought period, the ecosystem functioned as a $\mathrm{CH}_{4}$ sink, and during the extreme drought and post-drought periods, the ecosystem functioned as a net $\mathrm{CH}_{4}$ source (Figure $3 \mathrm{~b}$ ). Compared to the control treatment, extreme drought significantly decreased the $\mathrm{CH}_{4}$ fluxes of the Zoige peatland ecosystem by $31.54 \%(P<0.05$, Figure $3 \mathrm{~b}$, Table 1$)$ in the drought period, and there was no significant change in the pre and post-drought periods of the experiment under the extreme drought and control treatment $(P>0.05)$. Additionally, the difference of $\mathrm{CH}_{4}$ fluxes between the control and drought reached the highest value at the peak of plant growth (Figure 3c). The extreme drought significantly decreased SWC at depths of 5,10 , and $20 \mathrm{~cm}(P<0.05)$, but there was no significant influence of the extreme drought on Ts at depths of 5,10 , or $20 \mathrm{~cm}(P>0.05$, Table 1).

\subsection{Effects of extreme drought on plant biomass and soil physicochemical properties}

The extreme drought treatment significantly decreased the aboveground biomass of the Zoige alpine peatland ecosystem by $42.75 \%(P<0.05$, Figure $4 a)$. The extreme drought treatment significantly decreased the belowground biomass by $59.73 \%$ and $59.65 \%$ at a depth of $0-10 \mathrm{~cm}$ and $10-20 \mathrm{~cm}$, respectively $(P<0.05$, Figure $4 \mathrm{~b})$. Under both treatments, the root mass of the subsoil $(10-20 \mathrm{~cm})$ was higher than that of the topsoil $(0-10 \mathrm{~cm})$ (Figure $4 \mathrm{~b})$. Subsoil $(20 \mathrm{~cm})$ SWC was higher than that of the topsoil $(5,10 \mathrm{~cm})$ (Figure 4c). Significant differences in TC and TN between the two treatments were observed at a depth of 10-20 $\mathrm{cm}(P<0.05$, Figure $4 \mathrm{~d}-\mathrm{e})$, but there was no significant difference in TC or TN between the extreme drought treatment and control treatment at depths of $0-10 \mathrm{~cm}(P>0.05$, Figure $4 \mathrm{~d}-\mathrm{e})$. There was also no significant 
199

200

201

202

203

204

205

206

207

208

209

210

211

212

213

214

215

216

217

218

219

220

221

222

223

224

225

226

227

228

229

230

231

232

233

234

235

236

237

238

difference in SOC at depths of $0-10$ and $10-20 \mathrm{~cm}(P>0.05$, Figure $4 \mathrm{f})$. The organic matter (TC, $\mathrm{TN}$, and SOC) of the subsoil was lower than that of the top soil (Figure $4 \mathrm{~d}-\mathrm{f}$ ).

\subsection{Relationship between $\mathrm{CH}_{4}$ fluxes and environmental factors}

The regression analysis showed that the Ts at the depth of 10 and $20 \mathrm{~cm}$ had a significantly negatively relationship with $\mathrm{CH}_{4}$ fluxes between the two treatments $(P<0.05$, Figure $5 \mathrm{~b}-\mathrm{c})$, as the $\mathrm{CH}_{4}$ fluxes gradually decreased as the Ts increased. The correlation between the subsoil $(20 \mathrm{~cm})$ temperature and $\mathrm{CH}_{4}$ fluxes was higher than it was with the topsoil $(5,10 \mathrm{~cm})$ temperature between the two treatments (Figure 5a-c). The dynamics of the $\mathrm{CH}_{4}$ fluxes correlated well with that of the SWC, both in the extreme drought and control treatments (Figure $5 \mathrm{~d}-\mathrm{f}$ ). The SWC at depths of $5(P<0.01), 10(P<0.01)$, and $20(P<0.01) \mathrm{cm}$ was negatively correlated with the $\mathrm{CH}_{4}$ fluxes under the extreme drought and control treatments (Figure 5d-f). The correlation between the subsoil $(20 \mathrm{~cm})$ water content and $\mathrm{CH}_{4}$ fluxes was higher than it was with the topsoil $(5,10$ $\mathrm{cm})$ water content between the two treatments. Moreover, there was a significant difference in the slopes of the SWC at depths of 5,10, and $20 \mathrm{~cm}$ between the control and drought treatments ( $P_{\text {slope }}<0.01$, Figure $5 \mathrm{~d}-\mathrm{f}$ ). The slope of the $\mathrm{CH}_{4}$ fluxes under the extreme drought treatment was lower than that under the control treatment relative to the SWC. The correlation of $\mathrm{CH}_{4}$ fluxes to SWC was higher than it was relative to Ts (Figure 5a-f).

The correlation matrix analysis between $\mathrm{CH}_{4}$ fluxes and the different environmental factors at depths of 5,10, and $20 \mathrm{~cm}$ were negative under the two treatments. The correlation between $\mathrm{CH}_{4}$ fluxes and subsoil $(20 \mathrm{~cm})$ environmental factors (SWC and Ts) was higher than that with the topsoil $(5,10 \mathrm{~cm}$ ) environmental factors (Figure 6a-d). The extreme drought decreased the correlation between the Ts and $\mathrm{CH}_{4}$ fluxes (Figure 6a-b), and the extreme drought decreased the correlation between the $\mathrm{SWC}$ and $\mathrm{CH}_{4}$ fluxes (Fig 6c-d). There was a stronger relationship between the SWC and $\mathrm{CH}_{4}$ fluxes than between the Ts and $\mathrm{CH}_{4}$ fluxes (Figure 6a-d).

\section{Discussion}

The influence of extreme drought in relation to the variation of $\mathrm{CH}_{4}$ fluxes has been recognized in earlier studies [30,39-43]. For instance, $\mathrm{CH}_{4}$ fluxes measured by the eddy covariance method at Mer Bleue bog in Canada suggested that the total $\mathrm{CH}_{4}$ emitted during the growing season with extreme drought was less than that during the previous wetter year [44]. Meanwhile, three drought scenarios (gradual, intermediate, and rapid transition into drought) at 18 freshwater wetlands investigated in Everglades National Park, USA revealed that more $\mathrm{CH}_{4}$ was emitted than net carbon uptake could offset as the relative humidity increased [45]. Our study used a control experiment to simulate an extreme drought event for the reason that the controlled experiment had better consistency in soil and vegetation conditions. We analyzed the effects of extreme drought on $\mathrm{CH}_{4}$ fluxes and the relationship between $\mathrm{CH}_{4}$ fluxes and environmental factors in a typical alpine peatland. The results clearly showed that extreme drought significantly decreased the $\mathrm{CH}_{4}$ fluxes of the peatland ecosystem (Figure 3b), which was consistent with 
239 previous studies [43-46]. With the decrease of SWC and anaerobic degree, the transition from

240 anaerobic environment to aerobic environment decreased the generation of methane and

241 increased the thickness of the oxide layer, and the produced methane was oxidized by more

242 methanogens [47-49]. Extreme drought can also decrease the anaerobic environment of $\mathrm{CH}_{4}$

243 production and reduce the activity of methanogenic bacteria and anaerobic microsites, thus,

244 decreasing the emission of $\mathrm{CH}_{4}$ [49-51].

245 Extreme drought also had potential effects on different soil physical and chemical properties

246 [52-55]. Across the observed content of the soil organic matter, our results indicated that the soil

247 content of TN, TC, and SOC in the control treatment were higher than that under extreme

248 drought (Figs 4d-f). As previously reported, one possible explanation for this observation is that

249 drought might alter the distribution and transformation of carbon in the soil via the movement of

250 water and solutes through the pore matrix; thus, this might result the decrease of these matters

251 [54]. Additionally, with the vegetation coverage up to $90 \%$ and abundant rainfall during the

252 growing season in the Zoige alpine peatland, the large amount of methanol released from dead

253 plants will provide the substrate for methanogens, but the active conditions for methanogens

254 changes with the changing water conditions of the alpine peatland, resulting in reduced $\mathrm{CH}_{4}$

255 emission [55]. Our results also found that the soil contents of TN, TC, and SOC of the subsoil

$256(20 \mathrm{~cm})$ were lower than that of the topsoil $(5,10 \mathrm{~cm})$ (Figure 4d-f). In contrast, our results also

257 showed that there was a higher belowground biomass in the subsoil (Figure 4b) than the topsoil.

258 Moreover, a higher SWC in the subsoil $(20 \mathrm{~cm})$ was found relative to the topsoil (Figure 4c), and

259 this might have been because plants will allocate more roots to absorb more water and nutrients

260 in deeper soils, thus leading to a decreased SWC and soil organic matter [56].

261 Some prior studies have reported that environmental factors, including Ts and SWC, might

262 influence $\mathrm{CH}_{4}$ fluxes [57-59]. Across the study period, our results found that Ts had a significant

263 negative relationship with $\mathrm{CH}_{4}$ fluxes under control treatments at depth of 10 and $20 \mathrm{~cm}$ in the

264 Zoige peatland ecosystem, with the $\mathrm{CH}_{4}$ fluxes decreasing with the increasing of Ts (Figure 5b-

265 c). This negative relationship was in agreement with several studies [60-62], which suggested

266 that $\mathrm{CH}_{4}$ oxidation rates increased faster with increasing temperature when compared to $\mathrm{CH}_{4}$

267 production, leading to the decrease of $\mathrm{CH}_{4}$ fluxes. In addition, the alpine peatland is low-

268 temperature and anoxic all year round, but the oxygen content and temperature are increased

269 greatly in the peak period of plant growth, which provides an environment for methane oxidation

270 and enhances the activity of methane oxidative bacteria [58]. Additional results from this study

271 indicated that the correlation between subsoil $(20 \mathrm{~cm}) \mathrm{Ts}$ and $\mathrm{CH}_{4}$ fluxes was better than with the

272 topsoil $(5,10 \mathrm{~cm})$ Ts under these two treatments. This might have been due to the subsoil not

273 being easily disturbed by changes in the external environment, making it more suitable for the

274 survival of microorganisms related to methane production and oxidation [62]. Another founding

275 in this research was that extreme drought decreased the correlation of $\mathrm{CH}_{4}$ fluxes and Ts (Figure

276 6a-b). One possible explanation for this could be that extreme drought releases sulfate into the

277 soil solution, and this increase could stimulate sulfate-reducing bacteria, which could compete 
278 with methanogens for access to organic substrates that might sever to reduce the influence of Ts

279 on $\mathrm{CH}_{4}$ fluxes [63].

280 In addition to $\mathrm{Ts}, \mathrm{CH}_{4}$ fluxes are sensitive to the $\mathrm{SWC}$, and previous studies have shown a 281 strong relationship between the water table and $\mathrm{CH}_{4}$ emissions [63]. Here, we compared the 282 relationship between $\mathrm{CH}_{4}$ fluxes and the $\mathrm{SWC}$ at different depths and found that there was a 283 significant negative relationship between $\mathrm{CH}_{4}$ fluxes and SWC in the Zoige peatland ecosystem 284 (Figure 5). This might have been due to the increase of SWC hindering the diffusion of $\mathrm{CH}_{4}$ into 285 soil pores [64]. By comparing the slope of $\mathrm{CH}_{4}$ fluxes under extreme drought and control

286

287

288

289

290

291

292

293

294

295

296

297

298

299

300

301

302

303

304

305

306

307

308

309

310

311

312

313

314

315

316

317 treatments, we found that extreme drought significantly decreased the sensitivity of $\mathrm{CH}_{4}$ fluxes towards the SWC (Figure 5d-f). A possible explanation for this could be that extreme drought significantly decreased the SWC and changed the hydrothermal conditions of the soil, which could affect the production and oxidation of $\mathrm{CH}_{4}$ fluxes [65,67]. $\mathrm{CH}_{4}$-oxidizing microorganisms are able to be retrained under extreme drought conditions, resulting in a higher $\mathrm{CH}_{4}$ consumption during a drought, which could lead to the observed decreased sensitivity [66]. In addition, we found a better correlation between $\mathrm{CH}_{4}$ fluxes and subsoil SWC than for topsoil (Figure 6c-d). This might be due to the correlation of $\mathrm{CH}_{4}$ emissions and the concentration of $\mathrm{CH}_{4}$ dissolved in the pore water, which was controlled by rhizospheric oxidation of $\mathrm{CH}_{4}$ driven by plant photosynthesis [68]. With more water, the subsoil could provide a beneficial environment for higher methanogen activity [69]. However, a detailed analysis of the microbes and enzyme data is needed to explore these possible mechanisms in the future studies.

\section{Conclusions}

We found that the condition of extreme drought significantly decreased the $\mathrm{CH}_{4}$ fluxes in the Zoige peatland on the Tibetan Plateau. The Ts and SWC had negative relationships with $\mathrm{CH}_{4}$ fluxes under the extreme drought and control treatments. Extreme drought decreased the correlation of the $\mathrm{CH}_{4}$ fluxes relative to the $\mathrm{SWC}$ and weakened the sensitivity of $\mathrm{CH}_{4}$ fluxes towards the SWC. The correlation coefficient between the subsoil $(20 \mathrm{~cm})$ environmental factors and $\mathrm{CH}_{4}$ fluxes were higher than it was with the topsoil $(5,10 \mathrm{~cm})$ environmental factors under the extreme drought and control treatments. These findings indicated that extreme drought might reduce the contributions of $\mathrm{CH}_{4}$ emissions from high-altitude peatland into the atmosphere and decrease the global warming potential. However, the mechanism of $\mathrm{CH}_{4}$ fluxes affected by extreme drought remains unclear. As such, our further work will focus on the response of soil enzyme activity and soil microorganisms to extreme drought events and the coupling of microbial process and macroscopic phenomenon.

\section{Acknowledgements}

This work was supported by the National Nonprofit Institute Research Grant

(CAFYBB2017QB009), the National Key Research and Development Program of China (Grant No. 2016YFC0501804), and the National Natural Science Foundation of China (Grant No. 41701113, 41877421, 31770511). 


\section{References}

320 1. IPCC. Climate change 2013: the physical science basis. U.K. Cambridge: Cambridge

321 University Press 2013.

322 2. Kreyling, J.; Wenigmann, M.; Beierkuhnlein, C.; Jentsch, A. Effects of extreme weather

323 events on plant productivity and tissue die-back are modified by community composition.

324 Ecosystems 2008, 11, 752-763.

325 3. Kang, X.M.; Yan, L.; Cui, L.J.; Zhang, X.D.; Hao, Y.B.; Wu, H.D.; Zhang, Y.; Li, W.; Zhang, 326 K.R.; Yan, Z.Q.; Li, Y.; Wang, J.Z. Reduced carbon dioxide sink and methane source under 327 extreme drought condition in an alpine peatland. Sustainability 2018, 10, 4285.

328 4. Thakur, M.P.; Reich, P.B.; Hobbie, S.E.; Stefanski, A.; Rich, R.; Rice, K.E.; Eddy, W.C.; 329 Eisenhauer, N. Reduced feeding activity of soil detritivores under warmer and drier conditions. 330 Nat Clim Change 2017.

331 5. Reichstein, M.; Bahn, M.; Ciais, P.; Frank, D.; Mahecha, M.; Seneviratne, S.I.; Zscheischler, 332 J.; Beer, C.; Buchmann, N.; Frank, D.C.; Papale, D.; Ramming, A.; Smith, P.; Thonicke, K.; Van 333 der Velde, M.; Vicca, S.; Walz, A.; Wattenbach, M. Climate extremes and the carbon cycle.

334 Nature 2013, 500, 287-295.

335 6. Bloor, J.M.G.; Bardgett, R.D. Stability of above-ground and below-ground processes to 336 extreme drought in model grassland ecosystems: Interactions with plant species diversity and soil 337 nitrogen availability. Perspectives in Plant Ecology Evolution and Systematics 2012, 14, 0-204.

338 7. Beierkuhnlein, C.; Thiel, D.; Jentsch, A.; Willner, E.; Kreyling, J. Ecotypes of European grass 339 species respond differently to warming and extreme drought. Journal of Ecology 2011, 99, 703340713.

341 8. Hao, Y.B.; Cui, X.Y.; Wang, Y.F.; Mei, X.R.; Kang, X.M.; Wu, N.; Luo, P.; Zhu, D.

342 Predominance of precipitation and temperature controls on ecosystem $\mathrm{CO}_{2}$ exchange in Zoige 343 alpine wetlands of southwest China. Wetlands 2011, 31(2), 13-422.

344 9. Yin, Y.; Liu, H.Y.; Liu, G.; Hao, Q.; Wang, H.Y. Vegetation responses to mid-Holocene 345 extreme drought events and subsequent long-term drought on the southeastern Inner Mongolian 346 Plateau, China. Agricultural \& Forest Meteorology 2013, 178-179, 3-9.

347 10. Dargie, G.C.; Lewis, S.L.; Lawson, I.T.; Mitchard, E.T.A.; Page, S.; Bocko, Y.E.; Suspense, 348 I.A. Age, extent and carbon storage of the central Congo Basin peatland complex. Nature 2017, $349542,86-90$.

350 11. Page, S.E.; Rieley, J.O.; Banks, C.J. Global and regional importance of the tropical peatland 351 carbon pool. Global Change Biology 2011, 17, 798-818.

352 12. Wu, J. Response of peatland development and carbon cycling to climate change: a dynamic 353 system modeling approach. Environmental Earth Sciences 2012, 65, 141-151.

354 13. Mclaughlin, J.; Webster, K. Effects of climate change on peatlands in the far north of ontario, 355 canada: A synthesis. Arctic, Antarctic, and Alpine Research, 2014, 46(1), 84-102. 
356

357

358

359

360

361

362

363

364

365

366

367

368

369

370

371

372

373

374

375

376

377

378

379

380

381

382

383

384

385

386

387

388

389

390

391

392

393

394

14. van Bellen, S.; Garneau, M.; Booth, R. K. Holocene carbon accumulation rates from three ombrotrophic peatlands in boreal Québec, Canada: impact of climate-driven ecohyrological change. The Holocene 2011, 21, 1217-1231.

15. Bunbury, J.; Finkelstein, S.A.; Bollmann, J. Holocene hydro-climatic change and effects on carbon accumulation inferred from a peat bog in the Attawapiskat River watershed, Hudson Bay Lowlands, Canada. Quaternary Research, 2012, 78(2), 275-284.

16. Webster, K.L.; McLaughlin, J.W.; Kim, Y.; Packalen, M.; Li, C.S. Modelling carbon dynamics and response to environmental change along a boreal fen nutrient gradient. Ecological Modelling, 2013, 248, 148-164.

17. Reichstein, M.; Bahn, M.; Ciais, P.; Frank, D.; Mahecha, M.D.; Seneviratne, S.I.;

Zscheischler, J.Z.; Beer, C.; Buchmann, N.; Frank, D.C.; Papale, D.; Ramming, A.; Smith, P.;

Thonicke, K.; Van der velde, M.; Vicca, S.; Walz, A.; Wattenbach, M. Climate extremes and the carbon cycle. Nature,2013,500(7462).

18. Soren, N.M.; Sejian, V.; Malik, P.K. Enteric methane emission under different feeding systems. Springer 2015.

19. Wang, M.; Liu, Z.G.; Ma, X.H.; Wang, G.D. Division of organic carbon reserves of peatlands in China. Wetland Sciences 2012, 10(2), 156-163.

20. Kang, X.M.; Wang, Y.F.; Chen, H.; Tian, J.Q.; Cui, X.Y.; Rui, Y.C.; Zhong, L.; Kardol, P.; Hao, Y.B.; Xiao, X.M. Modeling carbon fluxes using multi-temporal MODIS imagery and $\mathrm{CO}_{2}$ eddy flux tower data in Zoige alpine wetland, south-west China. Wetlands 2014, 34, 603-618.

21. Rydin, H.; Jeglum, J.K. The biology of peatlands. Economic Botany 2006, 1-400.

22. Yang, G.; Chen, H.; Wu, N.; Tian, J.Q.; Peng, C.H.; Zhu, Q.A.; Zhu, D.; He, Y.X.; Zheng, Q.Y.; Zhang, C.B. Effects of soil warming, rainfall reduction and water table level on $\mathrm{CH}_{4}$, emissions from the Zoige peatland in China. Soil Biol Biochem 2014, 78, 83-89.

23. Gorham, E. Northern Peatlands: Role in the carbon cycle and probable responses to climatic warming. Ecol Appl 1991, 1, 182-195.

24. Chen, W.W.; Zheng, X.H.; Chen, Q.; Wolf, B.; Butterbach-Bahl, K.; Bruggemann, N.; Lin, S. Effects of increasing precipitation and nitrogen deposition on $\mathrm{CH}_{4}$ and $\mathrm{N}_{2} \mathrm{O}$ fluxes and ecosystem respiration in a degraded steppe in Inner Mongolia, China. Geoderma 2013, 192, 335340.

25. Blankinship, J.C.; Brown, J.R.; Dijkstra, P.; Allwright, M.C.; Hungate, B.A. Response of terrestrial $\mathrm{CH}_{4}$ uptake to interactive changes in precipitation and temperature along a climatic gradient. Ecosystems 2010, 13, 1157-1170.

26. Fest, B.J.; Nina, H.N.; Tim, W.; Griffith, D.W.T.; Livesley, S.J.; Arndt, S.K. Soil methane oxidation in both dry and wet temperate eucalypt forests shows a near-identical relationship with soil air-filled porosity. Biogeosciences 2017, 14, 467-479.

27. Huttunen, J.T.; Nykänen, H.; Turunen, J.; Martikainen, P.J. Methane emissions from natural peatlands in the northern boreal zone in Finland, Fennoscandia. Atmos Environ 2003, 37, 147151.

Peer) reviewing PDF | (2019:12:43962:1:2:NEW 18 Feb 2020) 
395

396

397

398

399

400

401

402

403

404

405

406

407

408

409

410

411

412

413

414

415

416

417

418

419

420

421

422

423

424

425

426

427

428

429

430

431

432

433

28. Freeman, C.; Nevison, G.B.; Kang, H.; Hughes, S.; Reynolds, B.; Hudson, J.A. Contrasted effects of simulated drought on the production and oxidation of methane in a mid-wales wetland. Soil Biol Biochem 2002, 34, 61-67.

29. Chen, H.; Wu, N.; Gao, Y.H.; Wang, Y.F.; Luo, P.; Tian, J.Q. Spatial variations on methane emissions from Zoige alpine wetlands of southwest China. Sci Total Environ 2009, 407, 1097 1104.

30. Wang, D.X.; Ding, W.X.; Wang, Y.Y. Influence of major environmental factors on difference of methane emission from Zoige plateau and Sanjiang plain wetlands. Wetland Science 2003.

31. Zhou, W.C.; Duoerji, S.; Cui, L.J.; Wang, Y.F.; Li, W. Effects of fencing and grazing on the emissions of $\mathrm{CO}_{2}$ and $\mathrm{CH}_{4}$ in Zoige peatland, East Qinghai-Tibetan plateau. Ecology \& Environmental Sciences 2015.

32. Hao, Y.B.; Kang, X.M.; Cui, X.Y.; Ding, K.; Wang, Y.F.; Zhou, X.Q. Verification of a threshold concept of ecologically effective precipitation pulse: from plant individuals to ecosystem. Ecol Inform 2012, 12, 23-30.

33. Wang, H.T.; He, X.D.; Gao, Y.B.; Lu, J.G.; Xue, P.P. Density in artemisia ordosica successional community in response to spatial heterogeneity of soil moisture and organic matter. Journal of Plant Ecology 2007, 31, 1145-1153.

34. Sokolova, O.V.; Vorozhtsov, D.L. Development of rapid method for determining the total carbon in boron carbide samples with elemental analyzer. Russian Journal of Applied Chemistry 2014, 87, 1640-1643.

35. Nozawa, S.; Hakoda, A.; Sakaida, K.; Suzuki, T.; Yasui, A. Method performance study of the determination of total nitrogen in soy sauce by the Kjeldahl method. Analytical Sciences the International Journal of the Japan Society for Analytical Chemistry 2005, 21(9):1129-1132. 36. Wickland, K.P.; Striegl, R.G.; Mast, M.A.; Clow, D.W. Carbon gas exchange at a southern Rocky Mountain wetland, 1996 1998. Global Biogeochem Cycles 2001, 15, 321 335. 37. Warton, D.I.; Wright, I.J.; Falster, D.S.; Westoby, M. Bivariate line-fitting methods for allometry. Biological Reviews 2006, 81, 259-291.

38. Svetnik, V.; Liaw, A.; Tong, C.; Wang, T. Application of Breiman's random forest to modeling structure-activity relationships of pharmaceutical molecules. Multiple Classifier Systems, 5th International Workshop 2004.

39. Harriss, R.; Sebacher, D.I.; Day, F.P. Methane flux in the Great Dismal Swamp. Nature. 1982, 297, 673-674.

40. Borken, W.; Davidson, E.A.; Savage, K.; Sundquist, E.T.; Steudler, P. Effect of summer throughfall exclusion, summer drought, and winter snow cover on methane fluxes in a temperate forest soil. Soil Biol Biochem 2006, 38, 1388-1395.

41. Stiehl-Braun, P.A.; Hartmann, A.A.; Kandeler, E.; Buchmann, N. Interactive effects of drought and $\mathrm{N}$ fertilization on the spatial distribution of methane assimilation in grassland soils. Glob Change Biol 2011, 17, 2629-2639. 
434 42. Hartmann, A.A.; Buchmann, N.; Niklaus, P.A. A study of soil methane sink regulation in two

435

436

437

438

439

440

441

442

443

444

445

446

447

448

449

450

451

452

453

454

455

456

457

458

459

460

461

462

463

464

465

466

467

468

469

470

471 grasslands exposed to drought and $\mathrm{N}$ fertilization. Plant Soil 2011, 342, 265-275.

43. Goodrich, J.P.; Campbell, D.; Schipper, L.A.; Clearwater, M. Summer drought leads to reduced net $\mathrm{CO}_{2}$ uptake and $\mathrm{CH}_{4}$ fluxes in a New Zealand peatland. AGU Fall Meeting Abstracts 2013.

44. Brown, M.; Humphreys, E.; Roulet, N.T.; Moore, T.R.; Lafleur, P. Divergent effects of drought on peatland methane emissions. AGU Fall Meeting Abstracts 2013.

45. Malone, S.L.; Starr, G.; Staudhammer, C.L.; Ryan, M.G. Effects of simulated drought on the carbon balance of everglades short-hydroperiod marsh. Glob Change Biol 2013, 19, 2511-2523. 46. Korres, N.E.; Norsworthy, J.K.; Burgos, N.R.; Oosterhuis, D.M. Temperature and drought impacts on rice production: An agronomic perspective regarding short- and long-term adaptation measures. Water Resources \& Rural Development 2017, 9, 12-27.

47. Smith, K.A.; Ball, T.; Conen, F.; Dobbie, K.E.; Massheder, J.; Rey, A. Exchange of greenhouse gases between soil and atmosphere: interactions of soil physical factors and biological processes. European Journal of Soil Science 2003, 54, 779-791.

48. Webster, K.L.; McLaughlin, J.W.; Kim, Y.; Packalen, M.S.; Li, C.S. Modelling carbon dynamics and response to environmental change along a boreal fen nutrient gradient. Ecological Modelling 2012, 248, 148-164.

49. Tiemeyer, B.; Borraz, E.A.; Augustin, J.; Bechtold, M.; Beetz, S.; Beyer, C.; Drosler, M.; Ebli, M.; Eickenscheidt, T.; Fiedler, S.; Forster, C.; Freibauer, A.; Giebels, M.; Glatzel, S.; Heinichen, J.; Hoffmann, M.; Hoper, H.; Jurasinski, G.; Leiber-Sauheitl, K.; Peichl-Brak, M.; Robkopf, N.; Sommer, M.; Zeitz, J. High emissions of greenhouse gases from grasslands on peat and other organic soils. Glob Change Biol 2016, 22, 4134-4149.

50. Tian, J.Q.; Zhu, Y.B.; Kang, X.M.; Dong, X.Z.; Li, W.; Chen, H.; Wang, Y.F. Effects of drought on the archaeal community in soil of the Zoige wetlands of the Qinghai-Tibetan plateau. Eur J Soil Biol 2012, 52, 84-90.

51. O'Connell, C.S.; Ruan, L.L.; Silver, W.L. Drought drives rapid shifts in tropical rainforest soil biogeochemistry and greenhouse gas emissions. Nat Commun 2018, 9, 1348.

52. Fenner, N.; Freeman, C. Drought-induced carbon loss in peatlands. Nat Geosci 2011, 4, 895900.

53. Yuste, J.C.; Peñuelas, J.; Estiarte, M.; Garcia-Mas, J.; Mattana, S.; Ogaya, R.; Pujol, M.; Sardans, J. Drought-resistant fungi control soil organic matter decomposition and its response to temperature. Glob Change Biol 2011, 17, 1475-1486.

54. Smith, A.P.; Bond-Lamberty, B.P.; Tfaily, M.M.; Todd-Brown, K.E.; Bailey, V.L. The destabilization of protected soil organic carbon following experimental drought at the pore and core scale. AGU Fall Meeting Abstracts 2015.

55. Jiang, N.; Wang, Y.F.; Dong, X.Z. Methanol as the primary methanogenic and acetogenic precursor in the cold Zoige wetland at Tibetan Plateau. Microbial Ecology 2010, 60(1):206-213. 
472 56. Johnson, D.M.; Sherrard, M.E.; Domec, J.C.; Jackson, R.B. Role of aquaporin activity in

473 regulating deep and shallow root hydraulic conductance during extreme drought. Trees 2014, 28,

474 1323-1331.

475 57. Morishita, T.; Hatano, R.; Desyatkin, R.V. $\mathrm{CH}_{4}$ flux in an alas ecosystem formed by forest

476 disturbance near Yakutsk, Eastern Siberia, Russia. Soil Science \& Plant Nutrition 2003, 49, 369-

477377.

478 58. Wei, D.; Xu, R.; Wang, Y.H.; Wang, Y.S.; Liu, Y.W.; Yao, T.D. Responses of $\mathrm{CO}_{2}, \mathrm{CH}_{4}$ and

$479 \mathrm{~N}_{2} \mathrm{O}$ fluxes to livestock exclosure in an alpine steppe on the Tibetan Plateau, China. Plant Soil

$480 \quad 2012,359,45-55$.

481 59. Krause, K.; Niklaus, P.A.; Schleppi, P. Soil-atmosphere fluxes of the greenhouse gases $\mathrm{CO}_{2}$,

$482 \mathrm{CH}_{4}$ and $\mathrm{N}_{2} \mathrm{O}$ in a mountain spruce forest subjected to long-term $\mathrm{N}$ addition and to tree girdling.

483 Agr Forest Meteorol 2013, 181, 61-68.

484 60. Conrad, R. Soil microorganisms as controllers of atmospheric trace gases $\left(\mathrm{H}_{2}, \mathrm{CO}, \mathrm{CH}_{4}\right.$, 485 OCS, $\mathrm{N}_{2} \mathrm{O}$, and NO). Microbiol Rev 1996, 60, 609-640.

486 61. Butterbach-Bahl, K.; Papen, H. Four years continuous record of $\mathrm{CH}_{4}$-exchange between the 487 atmosphere and untreated and limed soil of a N-saturated spruce and beech forest ecosystem in 488 Germany. Plant Soil 2002, 240, 77-90.

489 62. Koch, O.; Tscherko, D.; Kandeler, E. Seasonal and diurnal net methane emissions from 490 organic soils of the eastern Alps, Austria: effects of soil temperature, water balance, and plant 491 biomass. Arct Antarct Alp Res 2007, 39, 438-448.63. Dowrick, D.J.; Freeman, C.; Lock, M.A.;

492 Reynolds, B. Sulphate reduction and the suppression of peatland methane emissions following 493 summer drought. Geoderma 2006, 132, 384-390.

494 64. Luan, J.W.; Liu, S.R.; Wu, J.H.; Wang, M.; Yu, Z. The transient shift of driving 495 environmental factors of carbon dioxide and methane fluxes in Tibetan peatlands before and 496 after hydrological restoration. Agr Forest Meteorol 2018, 250-251, 138-146.

497 65. Borken, W.; Matzner, E. Reappraisal of drying and wetting effects on C and N mineralization 498 and fluxes in soils. Glob Change Biol 2010, 15, 808-824.

499 66. Einola, J.K.M.; Kettunen, R.H.; Rintala, J.A. Responses of methane oxidation to temperature 500 and water content in cover soil of a boreal landfill. Soil Biol Biochem 2007, 39, 1156-1164.

501 67. Wu, X.; Yao, Z.; Brüggemann, N.; Shen, Z.Y.; Wolf, B.; Dannenmann, M.; Zheng, X.;

502 Butterbach-Bahl, K. Effects of soil moisture and temperature on $\mathrm{CO}_{2}$ and $\mathrm{CH}_{4}$ soil-atmosphere

503 exchange of various land use/cover types in a semi-arid grassland in Inner Mongolia, China. Soil 504 Biol Biochem 2010, 42, 773-787.

505 68. Ding, W.; Cai, Z.; Tsuruta, H. Diel variation in methane emissions from the stands of carex 506 lasiocarpa and deyeuxia angustifolia in a cool temperate freshwater marsh. Atmospheric 507 Environment 2004, 38, 181-188.

508 69. Tian, J.Q.; Chen, H.; Wang, Y.F.; Zhou, X.Q. Methane production in relation with 509 temperature, substrate and soil depth in Zoige wetlands on Tibetan Plateau. Acta Ecologica 510 Sinica 2011, 31, 121-125.

511 


\section{Table $\mathbf{1}$ (on next page)}

Table 1. Results (P value) of effects of CH4 fluxes, Ts5, Ts10, Ts20, SWC5, SWC10 and SWC20 on block, date, drought, date*drought and date*block in 2017.

Ts 5/10/20, soil temperature at depth of 5,10 and $20 \mathrm{~cm}$; SWC 5/10/20, soil water content at depth of 5,10 and $20 \mathrm{~cm}$. 
1

\begin{tabular}{lccccccc}
\hline & $\mathrm{CH}_{4}$ fluxes & Ts5 & Ts10 & Ts20 & SWC5 & SWC10 & SWC20 \\
\hline Block & 0.679 & 0.960 & 0.999 & 0.900 & 0.072 & 0.066 & 0.034 \\
Date & $<0.001$ & $<0.001$ & $<0.001$ & $<0.001$ & $<0.001$ & $<0.001$ & $<0.001$ \\
Drought & 0.015 & 0.624 & 0.617 & 0.499 & 0.023 & 0.034 & 0.033 \\
Date*Drought & $<0.001$ & 0.775 & 0.960 & 0.937 & 0.354 & 0.883 & 0.499 \\
Date*Block & 0.006 & 0.623 & 0.994 & 0.947 & 0.100 & 0.790 & 0.793 \\
\hline
\end{tabular}


Figure 1

Figure 1.

(a) Zoige peatland in the eastern part of the Tibetan Plateau with the location of the study site, Sichuan province. (b) The picture of experiment site. (c) The zoning schematic map of experiment plot.

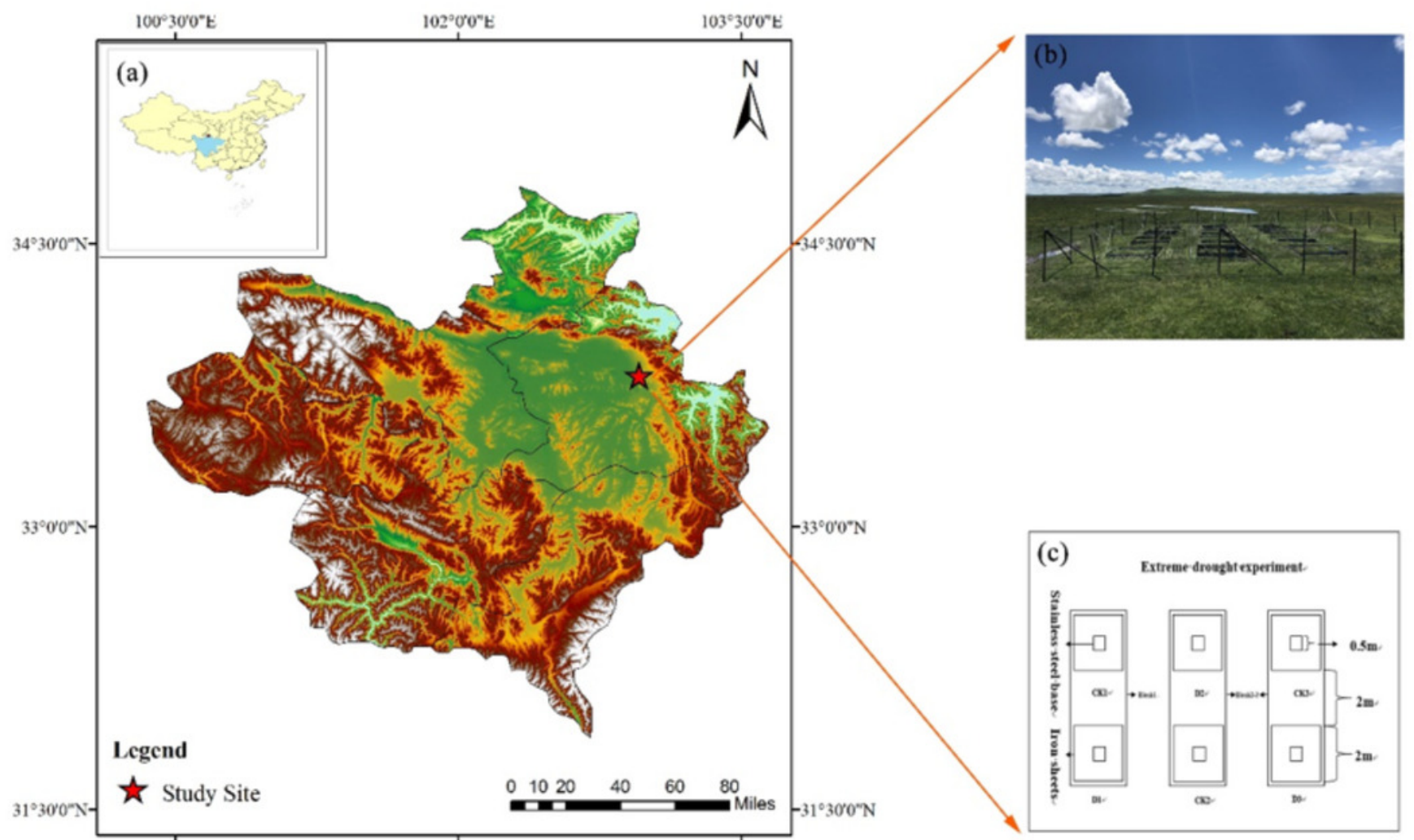

$100^{\circ} 30^{\circ} 0^{\circ} \mathrm{E}$

$102^{\circ} 0^{\circ} 0^{\circ} \mathrm{E}$

$103^{\circ} 30^{\circ} 0^{\circ} \mathrm{E}$ 
Figure 2

Figure 2.

Daily average precipitation and temperature of Zoige peatland during the experimental period in 2017. Point-line chart and histogram indicate temperature and precipitation respectively

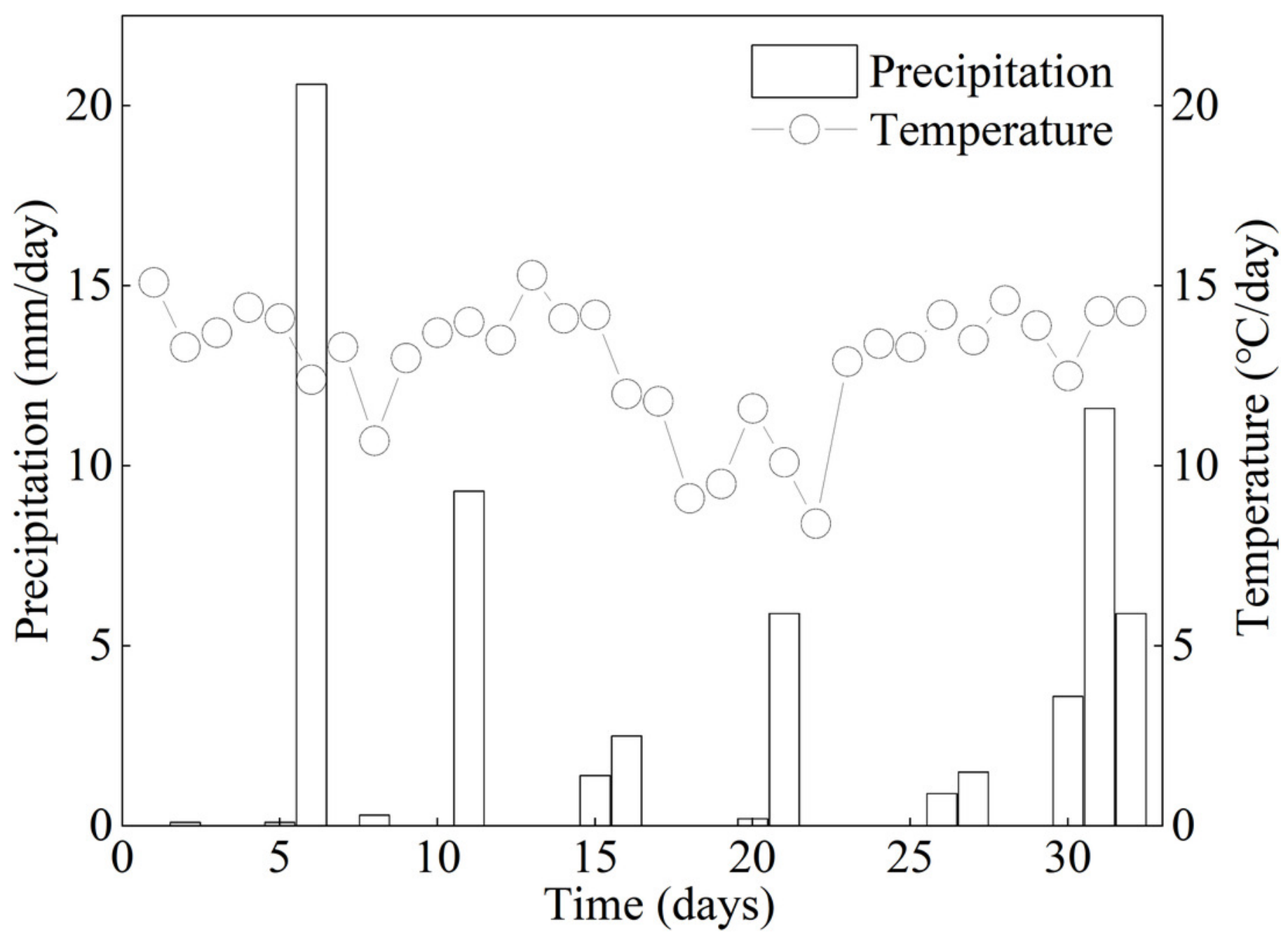


Figure 3

Figure 3.

(a) Effects of extreme drought on $\mathrm{CH}_{4}$ fluxes in 2017. (b) The total mean value at different periods. (c) The difference value between the extreme drought and control treatments. Bars show $\pm S E(n=3)$. The arrows indicate the dates of the experiment. *: statistically significant at $P<0.05$. CK, control; $\mathrm{D}$, extreme drought.
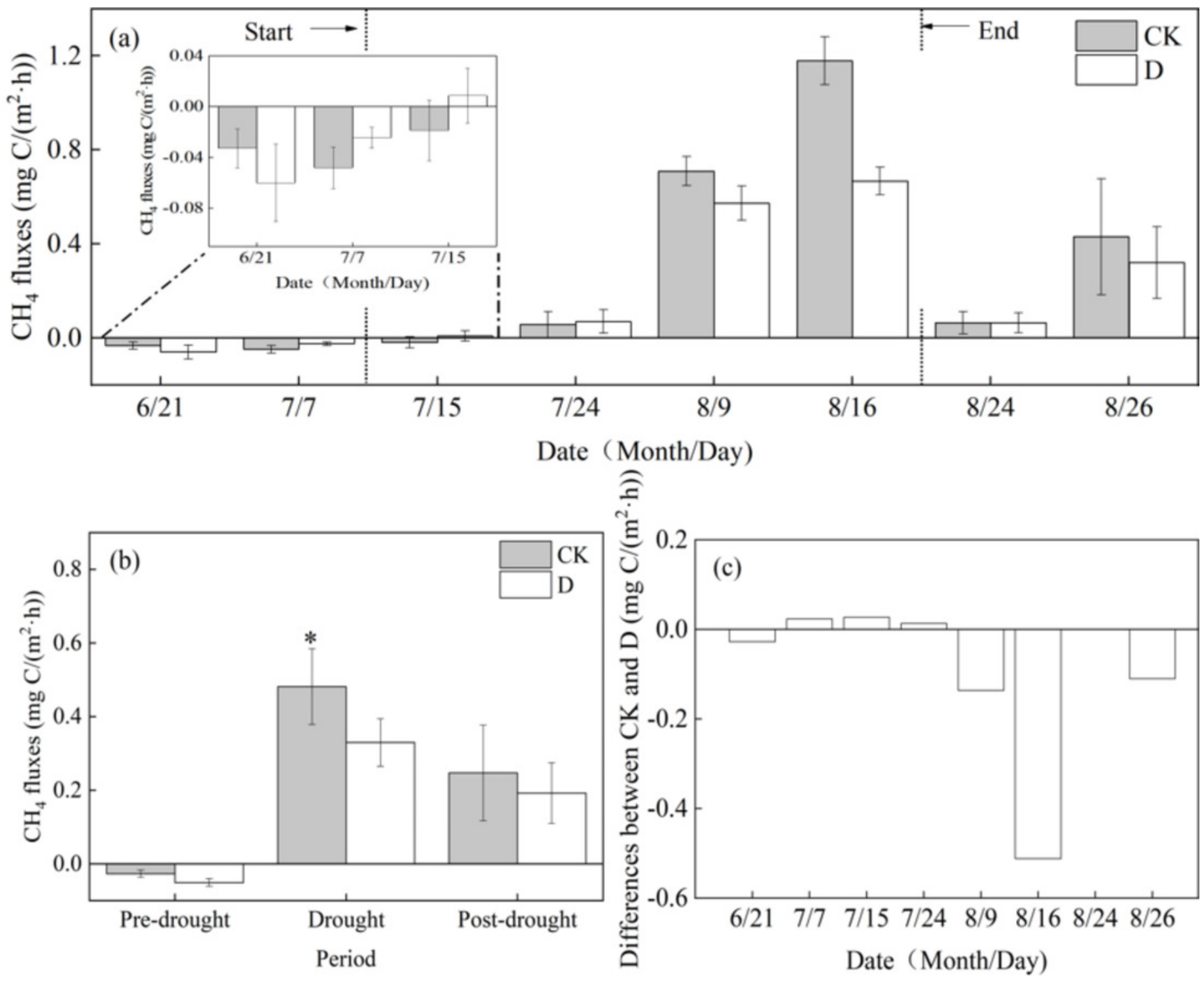
Figure 4

Figure 4.

(a) The impacts of extreme drought on aboveground biomass. (b) The impacts of extreme drought on belowground biomass. (c) The impacts of extreme drought on SWC at depths of 5, 10 and $20 \mathrm{~cm}$. (d) The effects of extreme drought on total nitrogen in the different soil layers. (e) The effects of extreme drought on total carbon in the different soil layers. (f) The effects of extreme drought on soil organic carbon in the different soil layers.

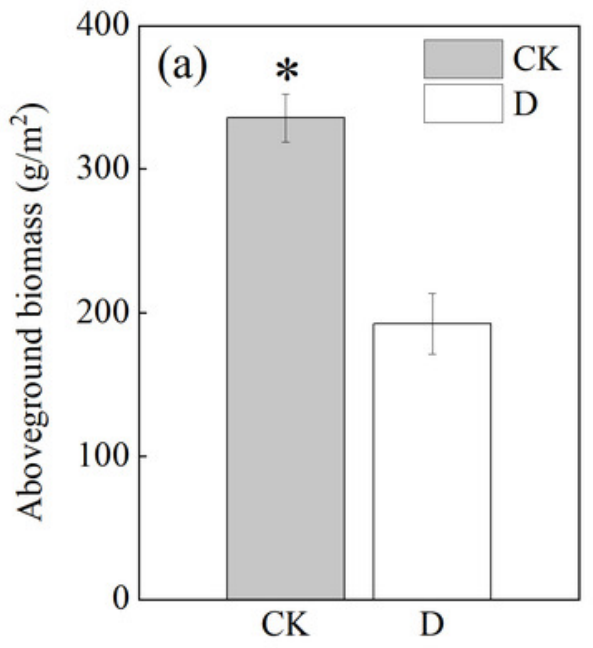

Treatment

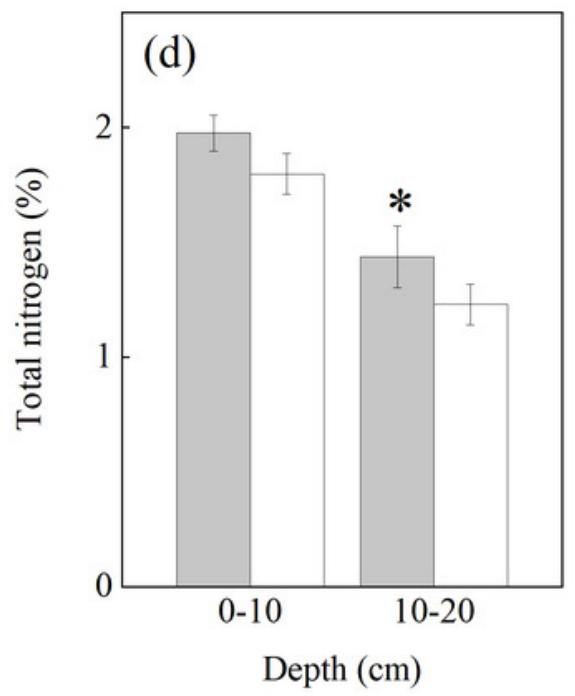

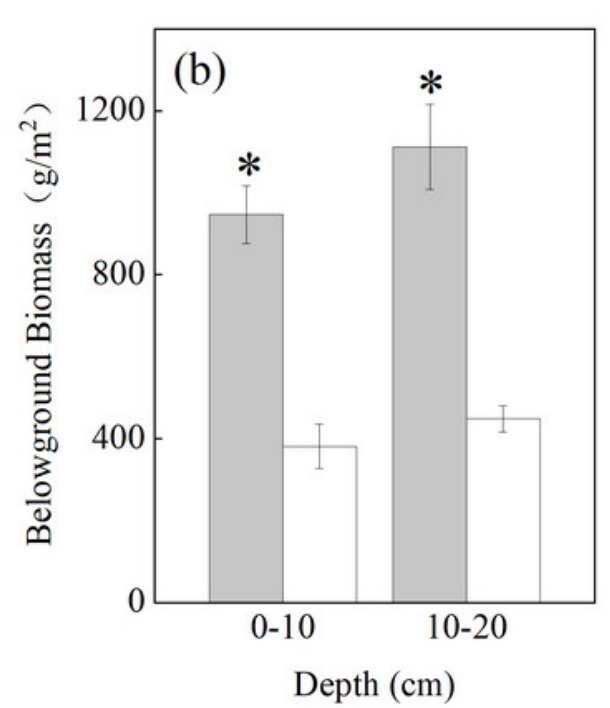

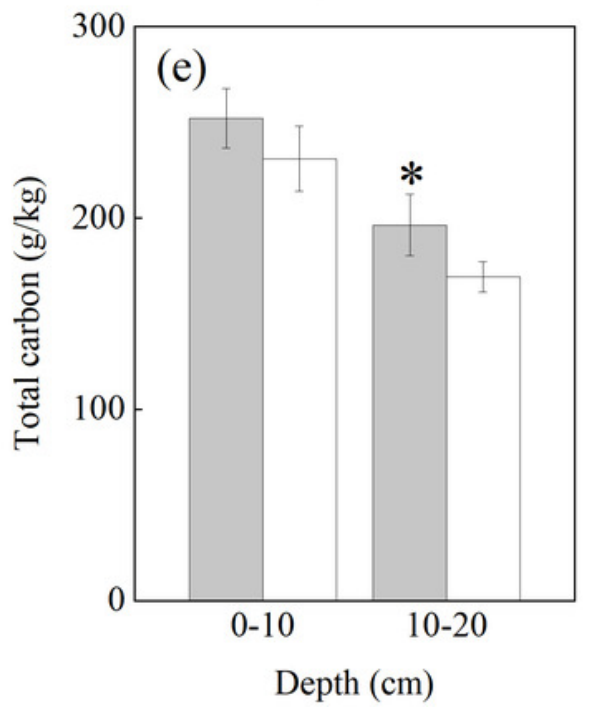

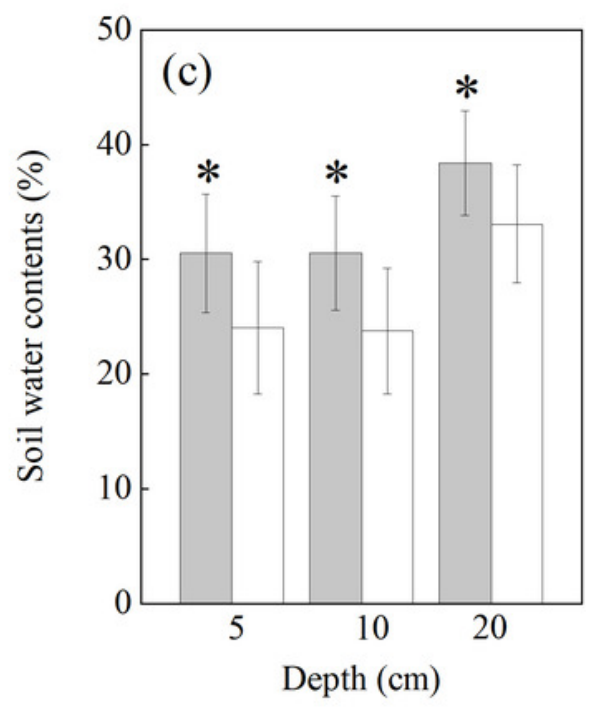

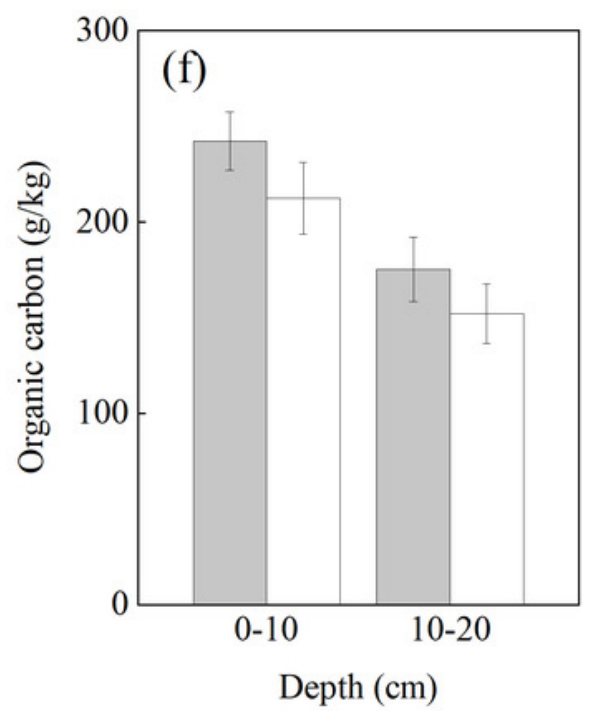




\section{Figure 5}

Figure 5.

Relationships between $\mathrm{CH}_{4}$ fluxes and (a) $5 \mathrm{~cm}$, (b) $10 \mathrm{~cm}$, and (c) $20 \mathrm{~cm}$ soil temperature, and the relationships between $\mathrm{CH}_{4}$ fluxes and (d) $5 \mathrm{~cm}$, (e) $10 \mathrm{~cm}$, and (f) $20 \mathrm{~cm} \mathrm{SWC}$ in the different treatments. $C K$, control; $D$, extreme drought. $P<0.05$ indicates a significant difference between $\mathrm{CH}_{4}$ fluxes and environment factors (Ts, SWC). $P_{\text {slope }}<0.05$ indicates a significant difference in the slopes between control and drought treatment.
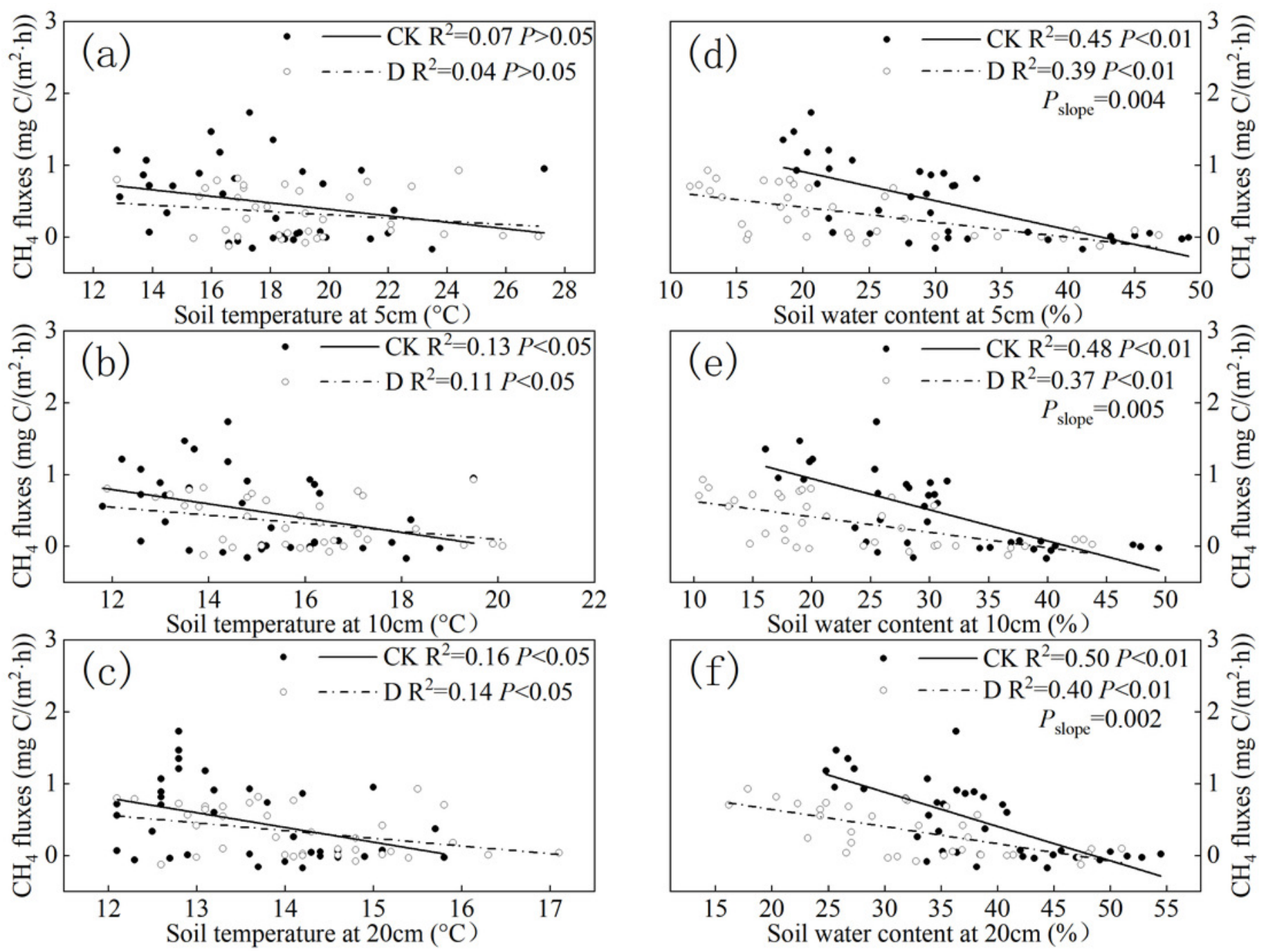


\section{Figure 6}

Figure 6.

(a) Correlation coefficient matrix for $\mathrm{CH}_{4}$ fluxes and Ts in the control treatment. (b)

Correlation coefficient matrix of $\mathrm{CH}_{4}$ fluxes and Ts in the extreme drought treatment. (c)

Correlation coefficient matrix between $\mathrm{CH}_{4}$ fluxes and SWC in the control treatment. (d)

Correlation coefficient matrix between $\mathrm{CH}_{4}$ fluxes and $\mathrm{SWC}$ in the extreme drought

treatment. Fluxes. CK, fluxes in control; Fluxes. D, fluxes in extreme drought; Ts $(5,10$, and $20 \mathrm{~cm})$, soil temperature at a depth of 5,10 , and $20 \mathrm{~cm}$; $\operatorname{SWC}(5,10$, and $20 \mathrm{~cm})$, soil water content at a depth of 5,10 , and $20 \mathrm{~cm}$. Light and dark red represent the degree of negative correlation. Light and dark blue represent the degree of positive correlation. 

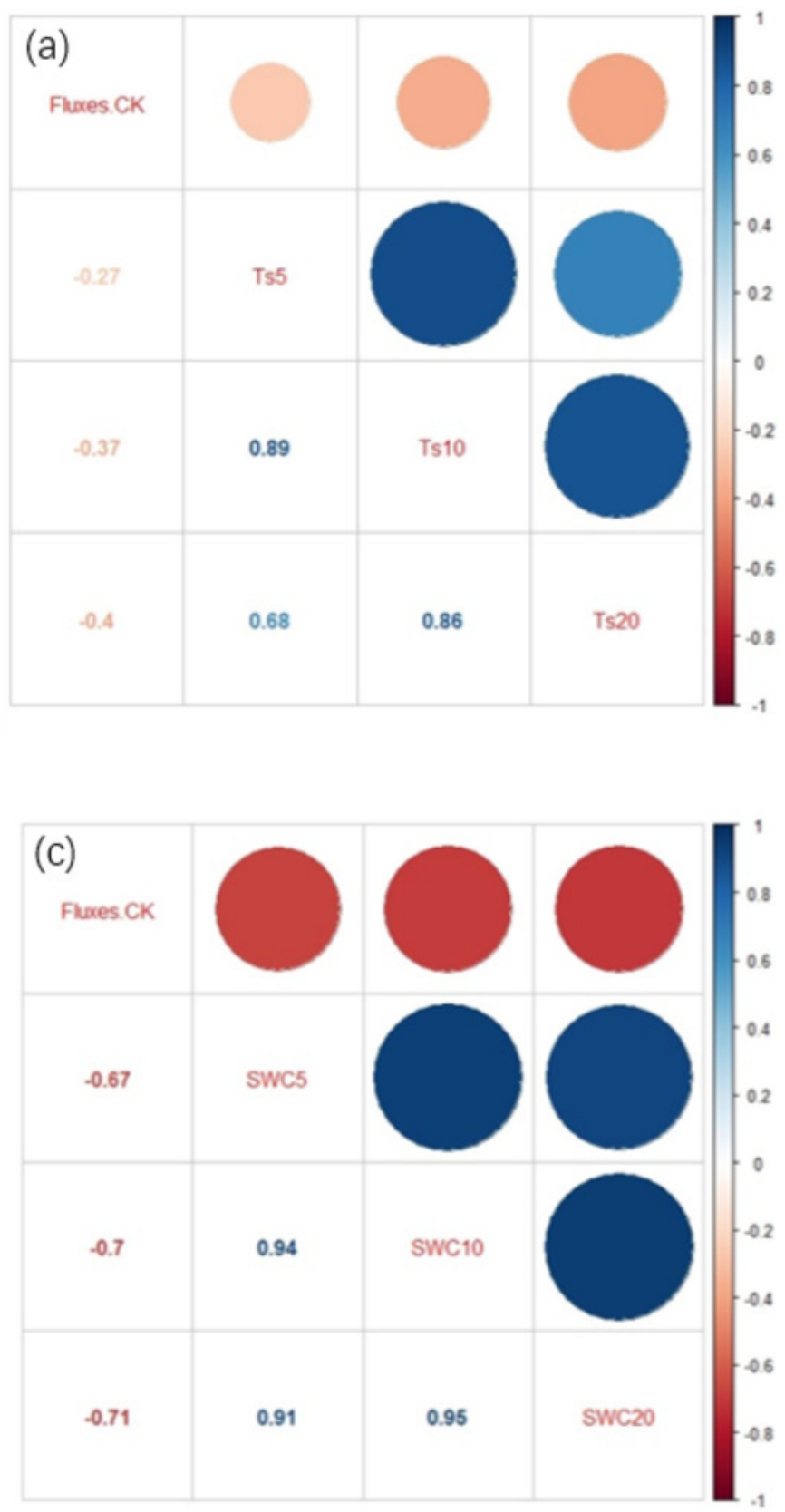
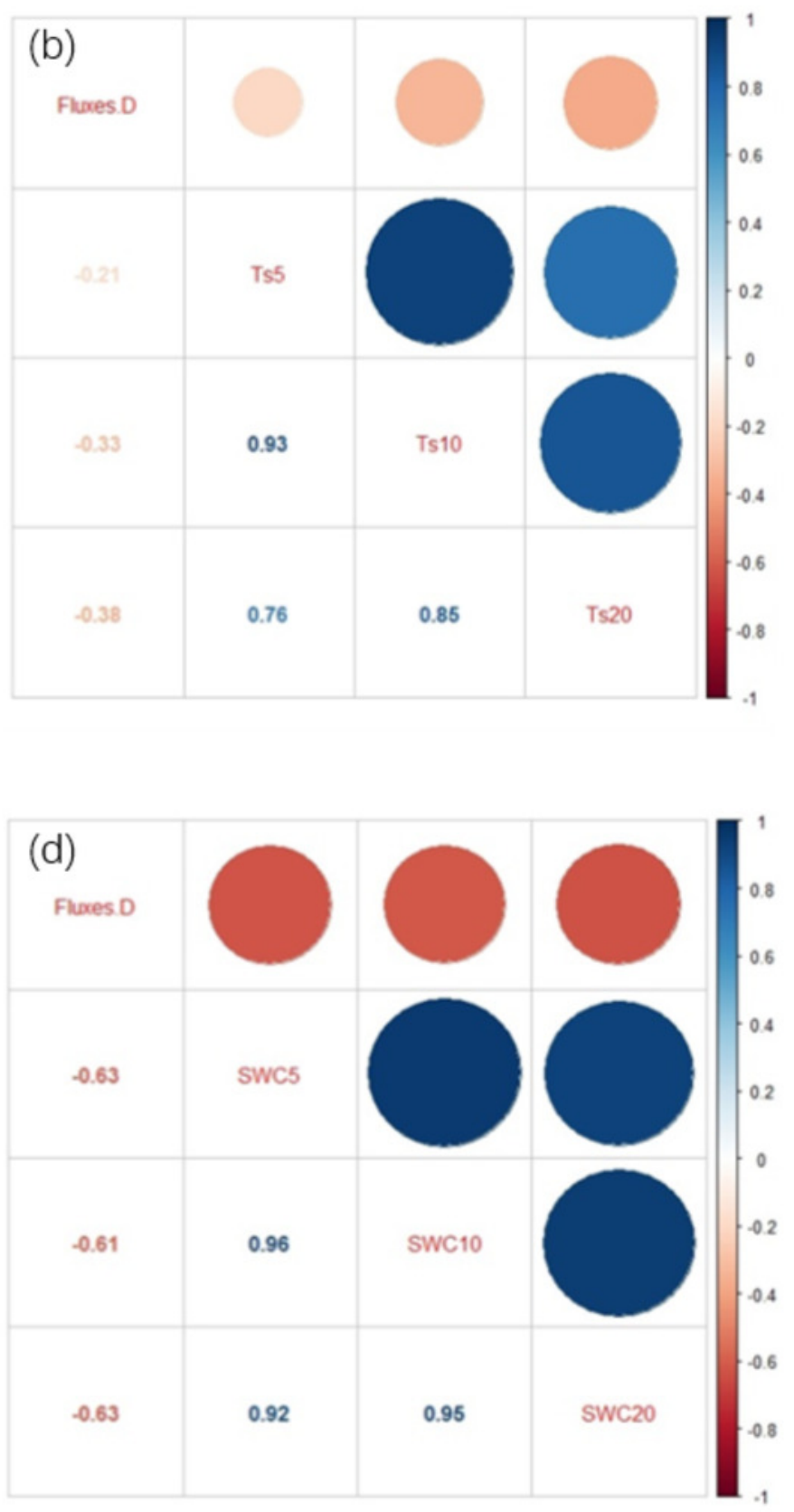